\title{
Rola procesowa opinii biegłych lekarzy na przykładzie praktyki Sądu Policji Prostej Okręgu Zgierskiego w Królestwie Polskim w latach 1851-1870
}

\section{Wstęp}

Najdrobniejsze sprawy karne jeszcze w okresie Księstwa War-

szawskiego poddane były jurysdykcji wydziału policyjnego sądu pokoju, który prowadził podsędek powiatowy ${ }^{1}$. Na obszarze łódzkim funkcjonował sąd policji prostej w ramach sądu pokoju, który miał swoją siedzibę początkowo w Zgierzu, a od 1864 r. przeniósł się do Łodzi ${ }^{2}$. Jurysdykcji tego sądu podlegały drobne sprawy policyjne, ponadto miał on za zadanie podjać pierwsze śledztwo i ustalić corpus delictỉ. Śledztwo $\mathrm{z}$ reguły prowadził podsędek, pisarz, podpisarz sądu pokoju4.

Akta sądu policji prostej zachowane w Archiwum Państwowym w Łodzi dokumentują praktykę zgierską i łódzką z lat 1851-1870. Najwięcej zachowało się teczek spraw o obelgi, potwarz i pobicie. Te wykroczenia policyjne występowały często również w praktyce późniejszej5.

Przy ustalaniu okoliczności faktycznych coraz większą rolę odgrywała medycyna sądowa ${ }^{6}$. W drobnych sprawach, w których trzeba było

${ }^{1} \mathrm{~W}$ okresie Królestwa Polskiego sądy policji prostej funkcjonowały nadal. Podsędków zastępować mogli asesorowie, pisarze i podpisarze sądu pokoju. S. Kutrzeba, Historya ustroju Polski w zarysie, t. III, cz. I, Po rozbiorach, Lwów 1920, s. 71-74, 104; A. Heylman, Historya Organizacyi Sądownictwa w Królestwie Polskiem, t. I, Warszawa 1861, s. 49, 80.

2 J. Machut-Kowalczyk, Początki łódzkiego sądownictwa, „Studia z Dziejów Państwa i Prawa Polskiego" [Kraków] 2014, t. XVII, s. 149-150.

${ }^{3}$ K. Małkowski, Przepisy postępowania sadowego w sprawach karnych. Wykład zasad procedury karnej. Dodatki historyczne. Prawo obowiazujące. Ordynacya Kryminalna Pruska i późniejsze prawodawstwo, Warszawa 1865, s. 174.

${ }^{4}$ S. Taylor, Ustrój sadowy w Księstwie Warszawskim i Królestwie do roku 1876-go, „Gazeta Sądowa Warszawska" [Warszawa] 1918, nr 41, s. 383.

${ }^{5}$ J. Machut-Kowalczyk, Początki łódzkiego..., s. 153.

${ }^{6} \mathrm{~W}$ omawianym okresie medycyna sądowa dopiero się rozwijała. W tygodniku lekarskim natrafiamy na ciekawe stwierdzenie: „Medycyna sądowa nie jest nową, odrębną 
określić stan zdrowia lub rozmiar doznanego uszczerbku na zdrowiu czy poznać mechanizm powstawania ran, pomocne były opinie lekarskie. Zadaniem lekarza było również wykrycie ewentualnego samookaleczenia się pokrzywdzonego ${ }^{7}$.

Postaramy się na podstawie ustawodawstwa ${ }^{8}$ i zachowanych w Archiwum Państwowym w Łodzi akt Sądu Policji Prostej Okręgu Zgierskie$\mathrm{go}^{9}$, krótko scharakteryzować rolę procesową tego środka dowodowego $\mathrm{w}$ rozstrzyganiu spraw policyjnych.

nauka; jest to tylko zastosowanie wszystkich nauk lekarskich do jednego celu, do poszukiwań sądowych", N., Zasady dochodzeń sądowo-lekarskich w przypadkach uszkodzeń ciała, wydane przez radę Lekarska Królestwa Polskiego. Redakcyi Członka Rady Profesora A. Jankowskiego, „Tygodnik Lekarski” [Warszawa] 1847, s. 201. W 1868 r. S. Budziński tak pisał o tej nauce pomocniczej prawa karnego: „Jest to systematyczny zbiór wiadomości, czerpanych z medycyny, chemii, fizyki i fizyologii, mający na celu wyjaśnienie wątpliwości, nastręczających się w prawie i procedurze karnej odnośnie do nienormalnego stanu zdrowia lub przyczyn śmierci". S. Budziński, Wykład porównawczy prawa karnego, Warszawa 1868, s. 8.

${ }^{7}$ Zasady dochodzeń sadowo-lekarskich w przypadkach uszkodzeń ciała, wydane przez Rade lekarska redakcyi członka rady A. Janikowskiego, Medycyna sąowa. O uszkodzeniach ciała, Warszawa 1847, s. 4.

${ }^{8}$ Prawo karne materialne i formalne do $1818 \mathrm{r}$. regulowane było przez prawo austriackie i pruskie, dopiero w 1818 r. wydany został Kodeks Karzący, a w 1847 r. Kodeks Kar Głównych i Poprawczych [dalej: KKGiP]. Proces karny w omawianej części Królestwa Polskiego, opierał się na Ordynacji Kryminalnej Pruskiej z 1805 r. i dekrecie z 26 VII 1810 r. pt. Organizacya Sądów Kryminalnych Wydziałów Policyi poprawczej i sadów Policyjnych w kraju przez Traktat Wiedeński do Księstwa Warszawskiego dołaczonym, S. Kutrzeba, Historya ustroju Polski w zarysie, t. III, cz. I, s. 74, 104, 117; A. Heylman, Historya Organizacyi Sadownictwa w Królestwie Polskiem..., s. 40, 49, 125; Postanowienie wprowadzajace w wykonanie Ustawe o Sadach Gminnych, z 30 maja/11 czerwca 1861 r. Ponadto przepisy z zakresu medycyny sądowej, m.in.: Rozporządzenie, aby na czele protokołów czynności sądowo lekarskich zamieszczany był urząd osób prowadzacych śledztwo i kwalifikacje lekarzy dopetniajacych obdukcyj, z 29 stycznia 1827 r., Komissya Rządowa Sprawiedliwości, nr 177; Instrukcya wskazująca Sądom zasady znoszenia się z zarzadem lekarskim do wszystkich Sądów Kryminalnych, Policyi Poprawczéj i Policyi Prostéj, z 8/20 kwietnia 1839 r., Dyrektora Głównego Prezydującego w Komisji Rządowej Sprawiedliwości, nr 179; Rozporządzenie, aby Sady o pierwotne opinie co do stanu zdrowia podsadnych, odnosity się nie do Członków Rady Lekarskiéj lub Urzędów Lekarskich, lecz do lekarzy rzadowych lub wolnopraktykujacych, 30 czerwca/11 lipca 1844 r., Kommissya Rzadowa Sprawiedliwości, nr 66, Zbiór Przepisów Administracyjnych Królestwa Polskiego [dalej: ZPAKP], Wydział Sprawiedliwości, cz. II, B. Organizacya sądownictwa karnego, t. XI, Przepisy dotyczace organizacyi sadownictwa karnego, Warszawa 1867, s. 32-35; Zasady dochodzeń sąowo-lekarskich co do watpliwego stanu zdrowia, postanowieniem Rady Administracyjnej z dnia 22 Maja (3 Czerwca) 1845 roku zatwierdzone i Sadom karnym przy reskrypcie z d. 26 Sierpnia (6 Września) 1845 roku, N. 11, 866, przesłane; Zasady dochodzeń sądowo-lekarskich w przypadkach uszkodzeń ciała, przez postanowienie Rady Administracyjnej z dnia 27 Maja (8 Czerwca) 1847 r. do stosowania się zalecone, ZPAKP, Wydział Sprawiedliwości, cz. II, B. Organizacya sądownictwa karnego [dalej: OSK], t. IX, Organizacya sadownictwa karnego, Warszawa 1867, s. 187.

${ }^{9}$ Zespół dokumentuje 117 spraw z lat 1851-1870. APŁ, zespół nr 120: Sąd Policji Prostej Okręgu Zgierskiego [dalej: SPPOZ], sygn. 2-106 (sygn. ta zawiera cztery osobne sprawy), 109-117. 


\section{Inicjatywa wydania opinii}

Jednym z elementów postępowania dowodowego było stwierdzenie i udokumentowanie skutków czynu zabronionego. Ocena obrażeń była zadaniem lekarza. Wydawał on opinię na wezwanie sądu lub innego urzędu, pokrzywdzonego, jego rodziny, albo sprawcy ${ }^{10}$. Nie mógł odmówić dokonania czynności sądowo-lekarskich na żądanie sądu ${ }^{11}$.

W praktyce lekarz wydawał opinię na polecenie sądu, organu policyjnego lub na prośbę prywatną. Na 27 zachowanych opinii w aktach Sądu Policji Prostej Okręgu Zgierskiego, jedynie w pięciu sprawach lekarz wydał opinię na wezwanie sądu lub organu policyjnego ${ }^{12}$. W innych przypadkach albo nie ma informacji na ten temat, albo zapisy w samej opinii sugerują inicjatywę prywatną jej wydania. Na przykład w opinii Lekarza Miasta Zgierza z 13 listopada 1862 r. czytamy: „Na żądanie przybyłej do mnie formanka, o godzinie 1 po południu, w dniu poniżej wyrażonym, Karoliny Schmidt"13.

Opinie w co najmniej 20 przypadkach zastały załączane do skargi ${ }^{14}$. Świadczy o tym powoływanie się przez pokrzywdzonych na nie ${ }^{15}$. Na przykład w skardze z 1/13 kwietnia 1863 r. czytamy: „oskarżeni napadli na moje mieszkanie, drzwi do niego wyłamali i zbili tak mnie, żonę moją i dzieci moje - obdukcja obrażenia obejmuje"16. W niektórych aktach znajdujemy adnotację, że skarżący złożył opinię lekarza ${ }^{17}$.

10 „§ 7. Opisanie dochodzenia uszkodzeń na osobie żyjącej, zwane poświadczeniem uszkodzenia (visum reprtum, parere) udzielane bywa przez lekarza na wezwanie władzy jakiej, lub też na żądanie osób prywatnych, jak np. uszkodzonego, krewnych jego, tego który uszkodzenie zrządził, i t.p.", Zasady dochodzeń sądowo-lekarskich w przypadkach uszkodzeń ciała..., s. 9.

${ }^{11}$ Art. 583 KKGiP, Kodex Kar Głównych i Poprawczych, „Dziennik Praw” [Warszawa] 1847 , t. XL, s. 445.

${ }^{12}$ Lekarz wystawiając opinię na wstępie informuje, że została wydana na wezwanie inspektora policji lub sądu. Np. „Na wezwanie Sądu Policyi Prostey Okręgu Zgierskiego”. SPPOZ, sygn. 65 [Sprawa przeciwko Karolowi Fryderykowi Grylich o pobicie i zagrożenie], k. 7.

${ }^{13}$ SPPOZ, sygn. 12, Sprawa przeciwko Samuelowi Herman [i innym] o pobicie z uszkodzeniem zdrowia, k. 2.

${ }^{14}$ SPPOZ, sygn. 38, Sprawa przeciwko Gustawowi i Rozali matż: Zielke o uszkodzenie na zdrowiu, k. 3-4; SPPOZ, sygn.15 [Sprawa przecizwko Mośkowi Brahman o pobicie], k. 1, 3.

${ }^{15}$ Niekiedy znajdujemy w skardze informację o zamiarze dostarczenia obdukcji przez skarżącego. Jednak mimo to nie natrafiamy na nią w aktach sprawy. Np. SPPOZ, sygn. 11, Sprawy przeciwko matżonkom Koś i małżonkom Engelhom o wzajemne pobicie i oszczerstwa, s. 7.

${ }^{16}$ SPPOZ, sygn. 33 [Sprawa przeciwko Józefowi Berkman i innym o pobicie], s. 2. Podobnie: SPPOZ, sygn. 9, Sprawa przeciwko Józefowi Franz i Robertowi Berger o obelgi, 1862, k. 2; SPPOZ, sygn. 30 [Sprawa przeciwko Franciszkowi Karolewskiemu, i innym o napad i rabunek], 1863, s. 4; sygn. 64, SPPOZ, sygn. 64, Sprawa przeciwko Edwardowi Henschel o uszkodzenie na zdrowiu, 1864/65, k. 3; SPPOZ, sygn. 89 [Sprawa przeciwko Gotfriedowi Straus o pobicie], 1865, s. 3; SPPOZ, sygn. 94 [Sprawa przeciwko Balle - płóciennikowi o pobicie], 1865, s. 3-4.

${ }^{17} \mathrm{~Np}$. SPPOZ, sygn. 39 [Sprawa przecizwo Adolfowi Bauch i innym o zabór mienia i pobicie], 1863, s. 2-3. 
Sąd policji prostej wnosił o wydanie opinii rzadko. Przykładem może być wezwanie podsędka J. Piaseckiego do lekarza Miasta Łodzi o udzielenie informacji dotyczącej pobytu w szpitalu pokrzywdzonego, jak i opisu jego obrażeń ${ }^{18}$. Lekarz miasta Łodzi odpowiedział na wezwanie przedstawiając żądane informacje 3/15 marca 1865 r. Na wstępie czytamy: „Na wezwanie Sądu Policyi Prostey Okręgu Zgierskiego z dn. 1/13 Marca r. b. № 330 - mam honor donieść co po zrewidowaniu Jozefa Rifler Czeladnika tkackiego, znalazłem następujące uszkodzenia na jego ciele"19.

W aktach spotykamy też opinie sporządzone na wezwanie inspektora policji. Przykładem może być opinia Lekarza Miasta Łodzi z 15/27 VIII 1865 r., na wstępie której czytamy: „Na wezwanie Woㅗ Inspektora Policyi Cyrkułu I - w dniu dzisiejszym pod № 1462 - mam honor donieść iż zrewidowałem mi nadesłaną Esther Belkicz"20.

\section{Biegły lekarz}

Prawo wymagało, aby opinie wydawali lekarze posiadający odpowiednią wiedzę ${ }^{21}$. Na początku protokołu z obdukcji, z boku, trzeba było podać kwalifikacje lekarza, który ją wykonał22.

K. Reinhard w swojej pracy poświęconej służbie zdrowia, narzekał na nieodpowiednie przygotowanie lekarzy („,urzędnicy lekarscy w obwodach i miastach, nie posiadając po większéj części odpowiednich stopni nie], k. 4

${ }^{18}$ SPPOZ, sygn. 65 [Sprawa przeciwko Karolowi Fryderykowi Grylich o pobicie i zagroże-

${ }_{19}$ SPPOZ, sygn. 65 [Sprawa przeciwko Karolowi Fryderykowi Grylich o pobicie i zagrożenie], k. 7. Podobnie: APŁ, zespół nr 120, SPPOZ, sygn. 66, Sprawa przeciwko Stefanowi Schultz o obelgi [i usiłowanie zabójstwa], 1865, k. 6.

${ }^{20}$ SPPOZ, sygn. 87, Sprawie przeciwko Esterze Dresler obelgi, k. 9. Podobnie: sygn. 41, SPPOZ, sygn. 41 [Sprawa przeciwko Ferdynandowi Hoffmanowi i innym o napad i pobicie], 1863, s. 5.

${ }^{21} \S 148$ OKP stanowił: „W każdym razie zanotować potrzeba, do Akt: że przybrany lekarz i felczer, za poprzedzaiącém doświadczeniem przez główne Kollegium lekarskie i chirurgiczne, zyskał upoważnienie do publicznego sprawowania sztuki lekarskiej i leczenia ran. Takowego atoli zanotowania nie potrzeba, co do Fizyka chirurgów reymentowych i batalionowych, niemniéy względzie Lékarzy ran, do czynności sądowych chirurgicznych iuż poprzysięgłych", Ordynacya Kryminalna Pruska, tłum. I. Stawiarski, Warszawa 1828, s. 54-55.

${ }^{22}$ Rozporządzenie, aby na czele protokołów czynności sadowo lekarskich zamieszczany byt urzad osób prowadzacych śledztwo i kwalifikacje lekarzy dopetniajacych obdukcyj, z 29 stycznia 1827 r., Komissya Rządowa Sprawiedliwości, nr 177, ZPAKP, OSK, t. XII. Przepisy dotyczace organizacyi sadownictwa karnego, Warszawa 1867, s. 389-391. 
naukowych i zbyt ogółowo znając medycynę sądową, albo nawet żadnych w tej mierze nie mając wiadomości, nie tylko że niezawsze załatwiać mogli żądania sądów z należytą dokładnością, lecz bezzasadnie ich opinie w sprawach kryminalnych, stawały się nieraz powodem do wydania wyroków ze stanem rzeczy niezgodnych. Skutkiem tego być musiało, że osoby mniéj winne, dotknięte niekiedy zostawały karami zbyt surowemi, a występek częstokroć uchodził bezkarnie" ${ }^{23}$ ). Zmiany zaczęły pojawiać się dopiero w latach trzydziestych XIX w. Egzaminowaniem osób ubiegających się o stopnie lekarskie i urzędy cywilno-lekarskie, zajmowała się wówczas Rada Lekarska ${ }^{24}$. Pierwszą instancją w czynnościach sądowo-lekarskich byli lekarze obwodowi (od 1842 r. powiatowi ${ }^{25}$. Drugą instancją były urzędy lekarskie ${ }^{26}$, a trzecią rada lekarska ${ }^{27}$.

W świetle instrukcji z 1839 r. sądy nie powinny poprzestawać na opinii lekarza miejskiego lub prywatnego, gdy opinia miała na celu ustalenie okoliczności czynu. Prawo wymagało wówczas przynajmniej zatwierdzenia takiej opinii przez lekarza obwodowego. Lekarze prywatni mający nieograniczone prawo do praktyki, byli obowiązani na wezwanie sądowe dokonywać czynności sądowo-lekarskich. Dotyczyło to jednak szczególnych wypadków, gdy nie było na miejscu lekarza powiatowego $^{28}$. Punkt 5 instrukcji z 1839 r. stanowił: „Lekarze miejscy po obwodach, którzy, w miarę potrzeby i funduszów, po niektórych miastach ustanowieni będą, obowiązani są do robienia śledzeń policyjno i sądowo-lekarskich mniejszej wagi. W przypadkach jednak niecierpiących zwłoki, na

${ }^{23}$ K. Reinhardt, Rzut oka na urzadzenie Stużby Zdrowia w królestwie Polskiém, „Biblioteka Warszawska" [Warszawa] 1846, t. III, s. 95.

${ }^{24}$ Jak podaje K. Reinhardt, w jej skład wchodzili: prezes, czterech członków etatowych, radcy farmaceutyczni, członkowie honorowi. Powołano do niej profesorów wydziału lekarskiego byłego królewskiego uniwersytetu, K. Reinhardt, Rzut oka..., s. 96-97.

${ }^{25}$ Punkt 2 instrukcji stanowił: „,Według $\$ 61$ Ustawy, lekarze obwodowi i ich pomocnicy obowiązani są w sprawach sądowych dawać opinie, które uważane być mają za opinie I-éj instancyi. Lekarze obwodowi i pod bezpośrednim ich kierunkiem działający pomocnicy, wyłącznie przeznaczeni są do robienia wszelkich bez wyjątku sądowo-lekarskich śledzeń, w powierzonym im obwodzie, oraz do sprawdzenia tych czynności, o ileby przez lekarzy miejskich, lub, w razie koniecznej potrzeby, przez wolno-praktykujących robione byli", Instukcya wskazujaca Sadom zasady znoszenia się z zarzadem lekarskim do wszystkich Sąów Kryminalnych, Policyi Poprawczéj i Policyi Prostéj, z 8/20 kwietnia 1839 r., Dyrektor Główny Prezydujący w Komissyi Rządowej Sprawiedliwości, nr 179, ZPAKP, OSK, t. XII. Przepisy dotyczące organizacyi sądownictwa karnego, Warszawa 1867, s. 399.

${ }^{26} \mathrm{Na}$ dwie gubernie przypadał jeden urząd lekarski. W jego skład wchodzili: inspektor urzędu, asesor farmacji, asesor weterynarii, członkowie honorowi, K. Reinhardt, Rzut oka..., s. 97.

${ }^{27}$ Instukcya wskazujaca Sadom zasady znoszenia się z zarzadem lekarskim do wszystkich Sądów Kryminalnych, Policyi Poprawczéj i Policyi Prostéj, z 8/20 kwietnia..., s. 403.

${ }^{28}$ Tamże, s. 399, 401. 
szczególne wezwanie władz sądowych, zdawać relacye obdukcyjne (visum et repertum), a nawet robić sekcye ciał są w obowiązku" ${ }^{29}$. W świetle rozporządzenia Komisji Rządowej Sprawiedliwości z 30 czerwca/11 lipca 1844 r. sądy powinny zwracać się o opinie również do lekarzy rządowych i wolnopraktykujących ${ }^{30}$.

W praktyce Sądu Policji Prostej Okręgu Zgierskiego mamy głównie do czynienia $z$ drobnymi obrażeniami ciała. $W$ aktach znajdujemy opinie w przeważającej większości lekarzy miejskich: Lekarza Miasta Łodzi ${ }^{31}$ i Lekarza Miasta Zgierza ${ }^{32}$. Opinie lekarza powiatowego spotykane są rzadko. Na 27 opinii udokumentowane są tylko dwa takie przypadki ${ }^{33}$, jedno świadectwo wystawione było przez lekarza „wolnopraktykującego" $^{\prime 34}$. Resztę opinii sporządzili lekarze miejscy.

\section{Forma}

Poświadczenie doznanego uszczerbku miało zwierać w sobie: oznaczenie podmiotu wnioskującego o wydanie opinii, czas i miejsce oraz sposób przybycia pokrzywdzonego na badanie. Poniżej powinny znajdować

29 Tamże, s. 399.

${ }^{30} \mathrm{~W}$ rozporządzeniu czytamy m.in.: „zaleca Sądowi Kryminalnemu dopilnowanie, aby w przypadkach wymagających pierwotnych opinij lekarskich, nie byli do tego przez Sądy używani Członkowie Rady Lekarskiéj, ani téż Członkowie Urzędów Lekarskich, jako ostatecznie w tym przedmiocie decydujący, lecz lekarze rządowi, posiadający zaufanie, lub nawet wolnopraktykujący", Rozporzadzenie, aby Sady o pierwotne opinie co do stanu zdrowia podsadnych, odnosity się nie do Członków Rady Lekarskiéj lub Urzędów Lekarskich, lecz do lekarzy rzadowych lub wolnopraktykujacych, 30 czerwca/11 lipca 1844 r., Kommissya Rzadowa Sprawiedliwości, nr 66, ZPAKP, OSK, t. XI. Przepisy dotyczace organizacyi sadownictwa karnego, Warszawa 1867, s. 35.

${ }^{31}$ SPPOZ, sygn. 31, Sprawa przeciwko Antoniemu Ulrych, Augustowi Gutsche o obelgi, 1860, s. 7; SPPOZ, sygn. 12, Sprawa przeciwko Samuelowi Herman [i innym] o pobicie z uszkodzeniem zdrowia, 1862, k. 2; SPPOZ, sygn. 14 [Sprawa przeciwko Augustowi Kacper i innym o pobicie], 1862, k. 2; SPPOZ, sygn. 89 [Sprawa przeciwko Gotfriedowi Straus o pobicie], 1865, k. 4; SPPOZ, APŁ, zespół nr 120, sygn. 112, Sprawa przeciwko Fryderykowi Kühn, Adamowi Letarskiemu i Michałowi Wolle o zagrożenie pozbawienia życia i obelgi, 1865, s. 9.

${ }^{32}$ SPPOZ, sygn. 12, Sprawa przeciwko Samuelowi Herman [i innym] o pobicie z uszkodzeniem zdrowia, 1862, k. 2; SPPOZ, sygn. 30 [Sprawa przeciwko Franciszkowi Karolewskiemu, i innym o napad i rabunek], 1862, s. 5; SPPOZ, sygn. 39 [Sprawa przeciwko Adolfowi Bauch i innym o zabór mienia i pobicie], 1863, k. 8; SPPOZ, sygn. 94 [Sprawa przeciwko Balle - płóciennikowi o pobicie], 1865, s. 7; SPPOZ, sygn. 111, Sprawa przeciwko Wilhelmowi Wagner, Dorocie Wagner o obelgi, 1865, s. 11-12.

${ }_{33}^{3}$ SPPOZ, sygn. 117, Akta Sadu Policji Prostej w Łodzi w sprawie przeciwko Michałowi Kowalskiemu o pobicie obwinionemu, 1870, k. 4.

${ }^{34}$ SPPOZ, sygn. 1 [Korespondencja z Prezydentem i Magistratem m. Łodzi], s. 266. 
się dane dotyczące pokrzywdzonego: wiek, budowa ciała, określenie stanu zdrowia. Następnym elementem opinii był opis uszkodzenia, sposobu jego powstania, wymienienie środków użytych przez lekarza i ich wpływ na stan zdrowia. Druga część opinii mogła znajdować się pod osobnym tytułem: „zdanie lekarskie”. Tu biegły powinien podać skutki wynikające z uszkodzenia ciała i ocenić możliwości wyleczenia. Na końcu miało znajdować się odwołanie do zasad przysięgi lekarskiej i do wykonanej przysięgi urzędowej (w przypadku urzędnika lekarskiego) lub oświadczenie gotowości zaprzysiężenia (gdy był to lekarz wolnopraktykujący). Urzędnik lekarski poza podpisem pieczętował opinię ${ }^{35}$.

Zweryfikujemy przedstawione wymagania z praktyką wydawania opinii w sprawach udokumentowanych w APŁ.

\subsection{Oznaczenie lekarza wydającego opinie}

W większości dokumentów, w ich górnej części widniała informacja, dotycząca kwalifikacji lekarza wystawiającego opinię. Na przykład „Lekarz Miasta Łodzi"36, „Lekarz Miasta Zgierza”37.

Opinie zawierały dwa stemple, jeden lekarski, drugi opłaty stemplowej. W dolnej części dokumentu znajdujemy najczęściej pieczątkę biegłego wydającego opinię: „Lekarz Miasta Łodzi” lub „Lekarz Miasta Zgierza". Obok niej zamieszczana była data wydania opinii i podpis biegłego. W górnej części dokumentu zamieszczany był stempel opłaty o wartości 7 i 1/2 kopiejek $^{38}$ lub 15 kopiejek $^{39}$. Niekiedy w lewym górnym rogu opinii pojawia się podpis podsędka poświadczającego stempel ${ }^{40}$.

${ }^{35}$ Zasady dochodzeń sądowo-lekarskich w przypadkach uszkodzeń ciała..., s. 10-11.

${ }^{36}$ SPPOZ, sygn. 31, Sprawa przeciwko Antoniemu Ulrych, Augustowi Gutsche o obelgi, 1860/1861, s. 7; SPPOZ, sygn. 89 [Sprawa przeciwko Gotfriedowi Straus o pobicie], 1865, k. 4; SPPOZ, sygn. 112, Sprawa przeciwko Fryderykowi Kühn, Adamowi Letarskiemu i Michałowi Wolle o zagrożenie pozbawienia życia i obelgi, 1865, s. 9.

${ }^{37}$ SPPOZ, sygn. 30 [Sprawa przeciwko Franciszkowi Karolewskiemu, i innym o napad i rabunek], s. 5; SPPOZ, sygn. 94 [Sprawa przecizwo Balle - płóciennikowi o pobicie], 1865, s. 7.

${ }^{38}$ SPPOZ, sygn. 9, Sprawa przeciwko Józefowi Franz i Robertowi Berger o obelgi, 1862, k. 3; Podobnie: SPPOZ, sygn. 31, Sprawa przeciwko Antoniemu Ulrych, Augustowi Gutsche o obelgi, 1860, s. 7; SPPOZ, sygn. 12, Sprawa przeciwko Samuelowi Herman [i innym] o pobicie z uszkodzeniem zdrowia, 1862, k. 2; APŁ, zespół nr 120, SPPOZ, sygn. 39 [Sprawa przeciwko Adolfowi Bauch i innym o zabór mienia i pobicie], 1863, s. 8.

${ }^{39}$ Np.: APŁ, zespół nr 120, SPPOZ, sygn. 106 [Sprawy różne], 1869, s. 12.

${ }^{40}$ Np.: APŁ, zespół nr 120, SPPOZ, sygn. 42 [Sprawa przeciwko Augustowi Apszpajgier i innym o napad, pobicie i zniszczenie cudzej własności], 1863, s. 6; SPPOZ, sygn. 89 [Sprawa przeciwko Gotfriedowi Straus o pobicie], 1865, k. 4. 


\subsection{Oznaczenie opinii}

Terminologia dotycząca opinii była różnorodna. W OKP terminu „obdukcja” używano w części poświęconej badaniu zwłok. „Relacja obdukcyjna" zaś dotyczyła wyników przeprowadzonego badania ${ }^{41}$. Prawodawca w stosunku do opinii lekarskiej używał pojęć: czynność, dochodzenie sądowo-lekarskie ${ }^{42}$, poświadczenie uszkodzenia, "visum et repertum"43, zdanie znawców, świadectwo lekarskie ${ }^{44}$, itd.

W praktyce obdukcję często określano: opinią, obdukcją świadectwem. Z reguły na górze znajdywał się tytuł. Opinia sporządzona w Aleksandrowie dnia 27 czerwca/9 lipca $1865 \mathrm{r}$. była zatytułowana „Visum et Repertum" ${ }^{\prime 4}$; „Poświadczenie uszkodzenia na ciele"46. Rzadziej znajdujemy zaświadczenia bez tytułu, opatrzone jedynie numerem ${ }^{47}$.

\subsection{Przebieg i rezultat badania}

W pierwszej kolejności zamieszczany był opis przebiegu badania i jego rezultat. W tym miejscu lekarz odnotowywał okazane mu obrażenia na ciele i zgłaszane przez badanego dolegliwości. W opinii Lekarza Miasta Zgierza z 27 czerwca/9 lipca 1865 r. czytamy: „,na powierzchni ciała jej nie znalazłem żadnych obrażeń". Następnie lekarz przedstawia zgłaszane przez pokrzywdzoną dolegliwości, szczególnie ból głowy i brzucha ${ }^{48}$.

W opinii Lekarza Miasta Łodzi z 22 sierpnia/3 września 1866 r. czytamy: „W dniu dzisiejszym stawił się przede mną Ludwik Gastley - z Miasta Aleksandrowa - w celu lekarskiego zrewidowania - a po obejrzeniu iego ciała okazał mi następujące uszkodzenia - które mu zadane zostały

${ }^{41}$ K. Małkowski, Przepisy postępowania..., s. 189-192.

${ }^{42}$ Art. 583 KKGiP.

${ }^{43}$ Zasady dochodzeń sądowo-lekarskich w przypadkach uszkodzeń ciała..., s. 9.

${ }^{44} \S 140$ OKP.

${ }^{45}$ Np.: SPPOZ, sygn. 31, Sprawa przeciwko Antoniemu Ulrych, Augustowi Gutsche o obelgi, 1860/1861, s. 7; SPPOZ, sygn. 39 [Sprawa przeciwko Adolfowi Bauch i innym o zabór mienia i pobicie], 1863, s. 8; SPPOZ, sygn. 94 [Sprawa przeciwko Balle - płóciennikowi o pobicie], 1865, s. 7; SPPOZ, sygn. 111, Sprawa przeciwko Wilhelmowi Wagner, Dorocie Wagner o obelgi, 1865, s. 11.

${ }^{46}$ SPPOZ, sygn. 30 [Sprawa przeciwko Franciszkowi Karolewskiemu, i innym o napad i rabunek], 1862, s. 5. Podobnie: SPPOZ, sygn. 12, Sprawa przeciwko Samuelowi Herman [i innym] o pobicie z uszkodzeniem zdrowia, 1862, k. 2.

${ }^{47}$ SPPOZ, sygn. 33 [Sprawa przeciwko Józefowi Berkman i innym o pobicie], 1863, s. 3-4.

48 SPPOZ, sygn. 111, Sprawa przeciwko Wilhelmowi Wagner, Dorocie Wagner o obelgi, s. 11-12. Podobnie: SPPOZ, sygn. 39 [Sprawa przeciwko Adolfowi Bauch i innym o zabór mienia i pobicie], 1863, s. 8; SPPOZ, sygn. 94 [Sprawa przeciwko Balle - płóciennikowi o pobicie], 1865, s. 7. 
- na grzbiecie nosa znajdowała się rana iuż strupem okryta - powieka dolna lewego oka i policzek podsinione [...] Oprócz tych uszkodzeń użala się także Ludwik Gastley na ból głowy i szum całego ciała" ${ }^{49}$.

\subsection{Wnioski}

W ostatnim akapicie zapisywana była ocena poniesionych przez badanego obrażeń. Niektóre opinie bardziej szczegółowo wskazywały nie tylko skutki powstałego uszczerbku na zdrowiu, ale również mechanizm ich powstawania. W jednej z nich, wydanej przez Lekarza Miasta Zgierza 11/23 czerwca 1863 r., czytamy: „Obrażenie to rzeczywiście powstać mogło od uderzenia w miejsce to ciałem twardem, lecz co się tyczy wymiotów krwią to takowe potrzebuje potwierdzenia przez świadków gdyż wyexaminowanie Sumienne nie potwierdziło tego" ${ }^{\prime 50}$.

Lekarz Miasta Zgierza 27 czerwca/9 lipca 1865 r. stwierdził: „Symptoma te patologiczne głowy i niektórych organów w jamie brzusznej zawartych a wyżej zaś wyszczególnionych - prawdopodobnie pochodzą od uderzenia ciałem twardém jak ręką oraz [...] również jak pobita twierdzi i z pchnięcia jak niemniéj: z upadnięcia [...] Z przyczyny, że środkami użytemi odsunięto niebezpieczeństwo co do życia - jednakże cierpienie do przejścia jego wymaga najmniej 5 do 6 dni lecz śladów na zdrowiu nadal pozostać nie powinno. Skutki więc pobicia należą do powierzchownych" ${ }^{51}$.

Najczęściej wnioski końcowe przybierały krótszą formę. Przykładowo: „Wyż opisane obrażenia do ciężkich policzyć nie można, iednak potrzeba od 6-8 dni czasu nim Gutsche do pierwotnego stanu zdrowia powróci" 52.

Niekiedy dodatkowo lekarz stwierdzał zdolność do uczestniczenia w czynnościach sądowych. W opinii z dnia 3/15 marca 1865 r., wydawanej na wezwanie sądu, po stwierdzeniu doznanego uszczerbku, Lekarz Miasta Łodzi stwierdził: "Jozef Ritter Każdego dnia może się stawić w Sądzie" ${ }^{\prime \prime 3}$.

${ }^{49}$ SPPOZ, sygn. 113, Sprawa przeciwko Wilhelmowi Mehring o uszkodzenie i zniszczenie znaków granicznych, s. 12.

${ }^{50}$ SPPOZ, sygn. 39 [Sprawa przecizwo Adolfowi Bauch i innym o zabór mienia i pobicie], s. 8.

${ }^{51}$ SPPOZ, sygn. 111, Sprawa przeciwko Wilhelmowi Wagner, Dorocie Wagner o obelgi, s. 1112. Podobnie: SPPOZ, sygn. 94 [Sprawa przecizko Balle - płóciennikowi o pobicie], 1865, s. 7.

${ }^{52}$ APŁ, zespół nr 120, SPPOZ, sygn. 31, Sprawa przeciwko Antoniemu Ulrych, Augustowi Gutsche o obelgi, 1860/1861, s. 7. Podobnie: SPPOZ, sygn. 15 [Sprawa przeciwko Mośkowi Brahman o pobicie], 1862, k. 3; SPPOZ, sygn. 14 [Sprawa przeciwko Augustowi Kacper i innym o pobicie], 1862, k. 2; SPPOZ, sygn. 42 [Sprawa przeciwko Augustowi Apszpajgier i innym o napad, pobicie i zniszczenie cudzej własności], 1863, s. 7.

${ }_{53}$ SPPOZ, sygn. 65 [Sprawa przeciwko Karolowi Fryderykowi Grylich o pobicie i zagrożenie], k. 7. 


\section{Znaczenie opinii}

Wadą skargi pokrzywdzonego był jej subiektywizm. Bardzo często pokrzywdzony wyolbrzymiał, ubarwiał stan faktyczny. Niekiedy wymyślał i niesłusznie oskarża ${ }^{54}$. Zadaniem lekarza w postępowaniu karnym było ustalenie faktycznego uszczerbku na zdrowiu albo rozwianie wątpliwości, co do stanu zdrowia osoby mającej uczestniczyć w czynnościach sądowych.

\subsection{Rola opinii przy ustalaniu kwalifikacji prawnej czynów i właściwości rzeczowej}

Spośród czynów spenalizowanych w KKGiP, opinie były przydatne w sprawach, w których skutek działania sprawcy (tu uszczerbek na zdrowiu) miał wpływ na odpowiednią kwalifikację prawną. Przykładem mogą być czyny uregulowane $\mathrm{w}$ rozdziale III - O zrzadzeniu kalectwa, ran $i$ innych uszkodzeń na zdrowiu i w rozdziale VI, oddziale II O bezpośrednich osobistych obelgach ${ }^{55}$. Problemy z kwalifikacją prawną pojawiają się przy czynie, który wypełnia znamiona tzw. obelg czynnych (art. 1010 ${ }^{56}, 1011 \mathrm{KKGiP}^{57}$ )

${ }^{54}$ K. Małkowski, Przepisy postępowania..., s. 32.

${ }^{55}$ Art. 1010-1012, 1018, itd., Kodex Kar Głównych i Poprawczych..., s. 735-741.

${ }^{56}$ Art. 1010 KKGiP: „Kto drugiemu osobistą więcej lub mniej ciężką obelgę wyrządzi, przez umyślne uderzenie go, przez zamierzenie się nań, pogrożenie mu innym sposobem, czyli to ręką, czyli jakiémkolwiek narzędziem, lub téż dopuszczenie się innego nieprzyzwoitego i obelżywego dlań czynu, ten, na zaskarżenie obrażonego, ulegnie: aresztowi od siedmiu dni do trzech miesięcy, stosownie do okoliczności winę jego zwiększających lub zmniejszających, a nadto obowiązany będzie przeprosić obrażonego, w myśl przepisów, w artykule 62 niniejszego Kodexu objętych [...]", tamże, s. 732-733.

${ }^{57}$ Art. 1011 KKGiP stanowił: „Jeżeli obelga osobista, przez uderzenie lub inny czyn obelżywy, wyrządzoną została z rozmysłem, wówczas winny, oprócz obowiązku przeproszenia obrażonego, ulegnie: osadzeniu w wierzy od trzech miesięcy do roku jednego, stosownie do okoliczności winę jego zwiększających lub zmniejszających. Lecz jeżeliby przy tém obrażonemu ciężkie, jakkolwiek życiu niebezpieczeństwem nie zagrażające pobicie umyślne zadaném zostało, winny, w miarę okoliczności winę jego zwiększających lub zmniejszających, ulegnie: zamknięciu w domu poprawy od roku jednego do dwóch lat, z utratą niektórych, w artykule 54 niniejszego Kodexu opisanych, szczególnych praw i przywilejów: albo osadzeniu w wieży od trzech miesięcy do roku jednego", tamże, s. 734-735. 
i uszkodzenia na zdrowiu (art. $950^{58}$ lub art. 955 KKGiP $^{59}$ ). Duże znaczenie przy kwalifikacji prawnej miał tutaj rozmiar doznanego przez pokrzywdzonego uszczerbku na zdrowiu ${ }^{60}$. W sprawach policyjnych trzeba wziąć pod uwagę jeszcze inne możliwości. Sądy Policji Prostej miały przejściowo na mocy postanowienia rady administracyjnej z 30 maja/11 czerwca $1861 \mathrm{r}$. stosować Ustawę o sądach gminnych wiejskich w Królestwie Polskiem z 1861 r. ${ }^{61}$ Przepisy dla sądów gminnych $\mathrm{w}$ dziale XIV zawierały regulacje dotyczące obelg (art. 742-750) ${ }^{62}$. Definicja obelgi podana została w art. 742 Ustawy o sadach gminnych wiejskich w Królestwie Polskiem: „Wyrządza obelgi: kto kogo uderzy, ale go ani skaleczy, ani zrani, ani mu innej szkody na zdrowiu nie zrobi" ${ }^{63}$.

\subsubsection{Rozwiązania ustawowe}

Gdy pokrzywdzony doznał uszczerbku na zdrowiu, do akt powinna być dołączona opinia lekarza ${ }^{64}$ § 140 OKP stanowił: „W zachodzących obrażeniach na ciele świadectwo aprobowanego lekarza ran, musi być

${ }^{58}$ Art. 950 KKGiP stanowił: „,Kto drugiemu inne mniej ciężkie kalectwo rozmyślnie zada, ten, również w miarę większego lub mniejszego rozmysłu z jakim działał, w miarę zrządzonych cierpień, wynikłéj ztąd dłuższej lub krótszéj niezdolności pokrzywdzonego do zwyczajnych zatrudnień i prac, tudzież stosownie do innych zwiększających winę okoliczności, ulegnie: zesłaniu na mieszkanie do Irkuckiej lub Jenisejskiéj gubernii, z zamknięciem od dwóch do trzech lat, i wzbronieniem wydalenia się do innych Syberyjskich gubernij w przeciągu zakreślonego przez sąd czasu od ośmiu do dziesięciu lat, albo zesłaniu na mieszkanie do Tomskiéj lub Tobolskiéj guernii, z zamknięciem od roku jednego do dwóch lat, lub bez zamknięcia, a jeżeli nie jest od kar cielesnych prawem wyłączony, oddaniu do poprawczych aresztanckich rot na czas od sześciu do ośmiu lat, lub od roku jednego do czterech lat", tamże, s. 688-689.

${ }^{59}$ Art. 955 KKGiP: „Kto, w zapalczywości lub gwałtowném uniesieniu, drugiemu ranę zada lub inne uszkodzenie na zdrowiu sprawi, wprawdzie bez rozmysłu, jednakże nie przypadkiem, lecz z przeświadczeniem o skutkach swego czynu, ten ulegnie, jeżeli rana takowa lub uszkodzenie są ciężkie, zesłaniu na mieszkanie do Tomskiej lub Tobolskiej gubernii, a jeżeli nie jest od kar cielesnych prawem wyłączony, oddaniu do poprawczych aresztanckich rot na czas od jednego do dwóch lat; jeżeli zaś rany lub uszkodzenia na zdrowiu są lekkie, osadzeniu w wieży od trzech do sześciu miesięcy", tamże, s. 693.

${ }^{60}$ Kwalifikacja konkretnych stanów faktycznych w sprawach o przestępstwa przeciwko nietykalności cielesnej w XX w., jak wskazuje G. Smyk, nadal nie była łatwa. G. Smyk, Przestępstwa przeciwko czci i nietykalności osobistej w prawie karnym II Rzeczypospolitej, [w:] Przestęsstwa przeciwko czci i nietykalności cielesnej, red. M. Mozgawa, Warszawa 2013, s. 58.

${ }^{61}$ S. Taylor, Ustrój sądowy w Księstwie Warszawskim..., s. 403. Art. 1 Postanowienia wprowadzającego w wykonanie Ustawe o Sadach Gminnych, z 30 V/11 VI 1861 r., Rady Administracyjnej, ZPAKP, OSK, t. X, Przepisy dotyczace organizacyi sadownictwa karnego, Warszawa 1867, s. 502.

62 „Dziennik Praw" [Warszawa] 1860, t. LVII, s. 287.

${ }^{63}$ Tamże.

${ }^{64}$ K. Małkowski, Przepisy postępowania..., s. 184. 
do akt dołączone" ${ }^{\prime \prime 5}$. Kolejne paragrafy regulowały postępowanie przy opiniach wątpliwych. Wówczas była możliwość skonfrontowania ze sobą opinii dwóch lekarzy ${ }^{66}$.

Gdy zachodziła potrzeba ustalenia skutków czynu zabronionego, w tym wysokości powstałej szkody, prawo wymagało zdania biegłego. § 135 Ordynacji Kryminalnej Pruskiej stanowił: „,Jeżeli skutek przestępstwa i szkoda przez nie zrządzona, oznaczaią wielkość kary, wyrokiem wskazać się maiącey, ta szkoda musi bydź wynaleziona pospolicie za przybraniem Znawców" ${ }^{\prime 67}$.

W przypadku ustalania rozmiaru doznanego przez pokrzywdzonego uszczerbku na zdrowiu liczył się czas, szczególnie gdy chodziło o lekkie obrażenia, które po upływie dwóch - trzech tygodni nie pozostawiały po sobie śladu. Od 1834 r., zgodnie z rozkazem Namiestnika Królestwa, dochodzenia sądowo-lekarskie miały odbywać się również w niedziele i dni świąteczne ${ }^{68}$. Lekarz, który zignorował obowiązek przeprowadzenia czynności sądowo-lekarskich podlegał karze (art. 583 KKGiP stanowił: „Lekarz powiatowy, miejski lub policyjny, który, bez szczególnych prawnych przeszkód, na prawne wezwanie do wyprowadzenia lekarsko sądowego dochodzenia się nie stawi, ulegnie: wytrąceniu trzech miesięcy z czasu służby. Lekarz zaś wolno praktykujący, który, wezwany w nieobecności lekarza powiatowego, miejskiego lub policyjnego, nie stawi się do podobnej czynności, ulegnie: karze pieniężnej od dziesięciu do pięćdziesięciu rubli" $)^{69}$.

\subsubsection{Praktyka}

Rolą lekarza była ocena stanu zdrowia, odniesionych przez pokrzywdzonego obrażeń. Obelgi czynne były czynem zabronionym, który nie pozostawiał trwałych śladów ${ }^{70}$. Inaczej było w przypadku spraw o pobicie. Potrzebna była tu opinia biegłego. Na jej podstawie sąd policji prostej kierował sprawę do sądu policji poprawczej lub organu administracji lokalnej (np. burmistrza, prezydenta).

Na 117 akt spraw sądu policji prostej, zachowanych w APŁ, w 41 przypadkach czyny początkowo kwalifikowane były jako pobicia, obelgi czynne czy wywołanie uszczerbku na zdrowiu. Opinię lekarską znajdujemy w 26 aktach spraw (w tym jednej dotyczącej potwarzy). W jednym

\footnotetext{
${ }^{65}$ Ordynacya Kryminalna Pruska..., s. 52.

${ }^{66} \S 141-148$ OKP, tamże, s. 52-55.

${ }^{67}$ Tamże, s. 51.

${ }^{68}$ ZPAKP, OSK, t. IX. Ustawa organiczna sadownictwa karnego, Warszawa 1867, s. 177.

${ }^{69}$ Kodex Kar Głównych i Poprawczych..., s. 445.

${ }^{70}$ S. Budziński, Wykład porównawczy prawa..., s. 155.
} 
przypadku, w którym nie ma opinii, pojawia się wzmianka o chęci jej złożenia przez skarżącą ${ }^{71}$.

Sąd z powodu braku opinii zmieniał kwalifikację prawną czynu. Na skardze wniesionej do Sądu Policji Prostej Okręgu Zgierskiego z 17/29 stycznia 1862 r., podsędek J. Piasecki odnotował: „Ex concluso Sąd etc.l W braku obdukcyi lekarskiej odnosi się do art. 742 ustawy dla Sądów Gminnych, w ślad więc postanowienia Rady Administracyjnej Królestwa, z d. 30 Maja/11 Czerwca 1861 r., akta Prezydentowi Miasta Łodzi dla wyprowadzenia śledztwa i p[...] w I Instancyi przesłać stanowi mocą tej decyzyi. Działo się w Zgierzu d. 24 Stycznia/5 Lutego 1862 r."72 Wcześniej obok powołanej kwalifikacji prawnej pojawił się art. 1010 KKGiP, również z powołaniem się na brak obdukcji ${ }^{73}$.

Podobna konkluzja widnieje na końcu opinii z 8/20 grudnia 1862 r. w sprawie uszkodzenia na zdrowiu, w której pokrzywdzoną była kobieta w ciąży. Tu jednak lekarz dodał: „jednak potrzeba mieć wzgląd na ciążę" ${ }^{74}$.

Sąd Policji Prostej Okręgu Zgierskiego w jednej ze spraw uznał się za niewłaściwy, kwalifikując sprawę jako czyn określony w art. 955 KKGiP. Podprokurator odpisał: „Obrażenia w obdukcji opisane do lżejszych należa, czyn więc do art. 742 UG. odnieść wypada, dlatego o odstąpienie sprawy pod wyrok Sądowi O-gu Zgierskiego wnoszę". Na odwrocie znajduje się postanowienie Sądu Policji Poprawczej Wydziału Łęczyckiego z 10/22 marca 1862 r., odsyłające sprawę Sądowi Policji Prostej Okręgu Zgierskiego $^{75}$. Sąd Policji Prostej Okręgu Zgierskiego, powołując się na postanowienie Rady Administracyjnej z 1862 r., przesłał 17/29 maja 1863 r. sprawę Prezydentowi Miasta Łodzi ${ }^{76}$. Podobna praktyka wystąpiła w 1864 r. przy sprawie o obelgi przeciwko Samuelowi Czamańskiemu. Sąd zakwalifiko-

\footnotetext{
${ }^{71} \mathrm{~Np}$.: SPPOZ, sygn. 11, Sprawy przeciwko małżonkom Koś i małżonkom Engelhom o wzajemne pobicie i oszczerstwa, s. 4 .

72 SPPOZ, sygn. 10, Sprawa przeciwko Zajdli Lubochińskiej żonie piekarza o obelgi słowne i czynne, s. 2. Podobnie: SPPOZ, sygn. 5, Sprawa przeciwko Geppertom Małżonkom o obelgi, 1861, k. 3; SPPOZ, sygn. 11, Sprawy przeciwko matżonkom Koś i matżonkom Engelhom o wzajemne pobicie i oszczerstwa, 1863, s. 1; SPPOZ, sygn. 79 [Sprawa przeciwko Szymchowi Landau o pobicie], 1865, s. 11-12; SPPOZ, sygn. 94 [Sprawa przeciwko Balle - płóciennikowi o pobicie], 1865 , s. 8.

${ }^{73}$ SPPOZ, sygn. 10, Sprawa przeciwko Zajdli Lubochińskiej żonie piekarza o obelgi stowne i czynne, k. 2.

${ }^{74}$ SPPOZ, sygn. 38, Akta sadu policyi poprawczej Wydziału Łęczyckiego w sprawie przeciwko Gustawowi Zielke o uszkodzenie na zdrowiu, k. 4.

${ }^{75}$ SPPOZ, sygn. 31, Sprawa przeciwko Antoniemu Ulrych, Augustowi Gutsche o obelgi, s. $35-37$.

${ }^{76}$ Tamże, s. 38-39.
} 
wał czyn do art. 955 KKGiP, Sąd Policji Poprawczej zwrócił jednak akta sprawy powołując się na opinię lekarza miasta Łodzi ${ }^{77}$.

W sprawie przeciwko Samuelowi Herman, mimo wniosku podprokuratora o rozpoznanie sprawy przez sąd poprawczy ${ }^{78}$, Sąd Poprawczy Wydziału Łęczyckiego przesłał 11/23 czerwca $1863 \mathrm{r}$. sprawę sądowi policji prostej, a ten Prezydentowi Miasta Łodzi 4/16 lutego 1864 r. ${ }^{79}$

Przykładem może być również postanowienie z 24 października/5 listopada 1864 r., wydane przez pisarza W. Janiszewskiego, za podsędka, które odnotowane zostało na skardze Anny z Przybylskich Micielskiej. Tu czytamy: „Sąd etc. Czyn zaskarżony przy braku obdukcyi i Opinii lekarskiej za odnoszący się do Art. 742 i 747. Ustawy Gminnej uznaje, a tem samem skargę Micielskiej w myśl Postanowienia Rady Administracyjnej Królestwa z dnia 30. Maja/: 11. Czerwca:/1861 r. Prezydentowi M. Łodzi do załatwienia odstąpić postanawia" ${ }^{80}$.

W skardze o obelgi słowne i czynne skarżący również powołuje się na opinię lekarza, opisując przy tym zachowanie obwinionych i odniesione przez siebie obrażenia („oskarżeni rzucili się na mnie i tak gwałtownie mnie pokrzywdzili, że jak obdukcya Wgo Szerzel Lekarza miasta przekonywa od pobicia tego chorowałem i jeszcze dotąd słaby jestem, oskarżeni bowiem oprócz policzkowania mnie kąsali mnie zębami i to do tego stopnia że mi dziury i rany pozadawali"81. Powołana obdukcja stwierdzała rany na dłoni i ramieniu. Ogólnie jednak, obrażenia według Lekarza Miasta Łodzi nie należały do ciężkich ${ }^{82}$. Sąd na podstawie tej opinii przyjął kwalifikację prawną czynu - art. 472 Ustawy dla sądów gminnych i odesłał akta dla przeprowadzenia śledztwa ${ }^{83}$.

77 „Gdy według świadectwa obejrzenia Rozalii Landau - dopełnionego przez lekarza miasta Łodzi - ta nie doznała skaleczenia, ani zranienia - tylko obrażenia na trzech sińcach ograniczającego się - według zdania tegoż Lekarza niemogącego się liczyć do ważniejszych obrażeń - przeto czyn zaskarżony zdaje się odnosić do Art. 742 Ust. Gmin. - Akta te podać do wniosków na względzie odstąpienia tej sprawy pod wyrok Sądowi Policyi Prostej Okręgu Zgierskiego - Łęczy: d. 27 Listop./ 9 Grud. 1864 r.", SPPOZ, sygn. 63, Sprawa przeciwko Samuelowi Czamańskiemu o obelgi, k. 13.

${ }^{78}$ We wniosku podprokuratora czytamy: „Obrażenia w obdukcyi opisane a mianowicie rozcięcie wargi górnej do ważniejszych należa, dla tego o zawyrokowanie sprawy w Sądzie Poprawczym wnosze - Łęczyca 17 Czerwca 63 r.", SPPOZ, sygn. 12, Sprawa przeciwko Samuelowi Herman [i innym] o pobicie z uszkodzeniem zdrowia, k. 9.

${ }^{79}$ Tamże.

${ }^{80}$ SPPOZ, sygn. 57 [Sprawa przeciwko Józefowi Mycielskiemu i jego siostrze, Józefie Holwek o oszczerstwo i pobicie], k. 1.

${ }^{81}$ SPPOZ, sygn. 86 [Sprawa przeciwko Janowi Benke i innym o oszczerstwo], 1864, k. 1.

${ }^{82}$ Tamże, k. 2.

${ }^{83} \mathrm{SPPOZ}$, sygn. 41 [Sprawa przeciwko Ferdynandowi Hoffmanowi i innym o napad i pobicie], s. 5-6; SPPOZ, sygn. 89 [Sprawa przeciwko Gotfriedowi Straus o pobicie], 1865, k. 4. 
Pod opinią Lekarza Miasta Łodzi na tej samej stronie znajdujemy adnotację: "Conclusum Sąd etc. Przedmiotem tej sprawy są obelgi czynne, które wedle obdukcyi lekarskiej pozostawiły po sobie tylko obrażenia powierzchowne" ${ }^{\prime \prime 4}$. Na kolejnej karcie znajdujemy zarządzenie podsędka J. Piaseckiego: „wezwać Prezydenta Miasta Łodzi o uwolnienie z aresztu podsądnego" ${ }^{\prime 25}$.

W innej sprawie znajdujemy następujące zarządzenie podsędka J. Piaseckiego, z 5/17 III 1866 r.: „Conclusum Sąd etc. Czyn wedle skargi co do pobicia przy uwadze na obdukcyię lekarską do art. 955 KKGiP [...] w myśl więc art. 23 U. P. akta tej sprawy Sądowi policyi poprawczej Wydziału Łęczyckiego do dalszego postąpienia przesłać stanowi"86. Opinia jednak świadczyła, że obrażenia nie są ciężkie i po 8-10 dniach pokrzywdzona wróci do zdrowia ${ }^{87}$. Decyzją Sądu Policji Poprawczej Wydziału Łęczyckiego z 4 maja 1865 r., akta sprawy zostały zwrócone, jako odnoszące się do art. 742, $745 \mathrm{UG}^{88}$. Sąd policji prostej „odstąpił sprawę Burmistrzowi Miasta Aleksandrowa" ${ }^{89}$.

W aktach Sądu Policji Prostej Okręgu Zgierskiego nie znajdujemy przypadków, w których opinia wydana przez lekarza była kwestionowana.

\subsection{Inne zastosowanie}

Opinie wydawane na wezwanie sądu były związane z możliwością uczestniczenia w czynnościach sądowych. Lekarz oceniał stan zdrowia. Zasady postępowania $w$ przypadkach wątpliwego stanu zdrowia regulowane były postanowieniem rady administracyjnej z 22 maja/3 czerwca $1845 \mathrm{r}^{90}$ W jednej z dwóch części tej instrukcji opisane były, jak podaje K. Reinhard, „wątpliwe choroby ciała udawane, wmawiane lub ukrywane" ${ }^{\prime 1}$. Do zbioru zasad załączone zostały przykładowe zdania lekarskie dotyczące udawa-

\footnotetext{
${ }^{84}$ SPPOZ, sygn. 65 [Sprawa przeciwko Karolowi Fryderykowi Grylich o pobicie i zagrożenie], 1865, k. 7.

${ }^{85}$ Tamże, k. 8. Podobnie: SPPOZ, sygn. 66, Sprawa przecizwo Stefanowi Schultz o obelgi [i usiłowanie zabójstwa], 1865, k. 7.

${ }^{86}$ SPPOZ, sygn. 112, Sprawa przeciwko Fryderykowi Kühn, Adamowi Letarskiemu i Michałowi Wolle o zagrożenie pozbawienia życia i obelgi, s. 28.

${ }^{87}$ Tamże, s. 9.

${ }^{88}$ W piśmie Sądu Policji Poprawczej Wydziału Łęczyckiego czytamy: „W myśl decyzyi Sądu tutejszego daty dzisiejszej stosującej czyn dochodzony do art. 742. 745. Ust: Gmin. Akta sprawy pko: Ferdynandowi Kühn przesyła pod wyrok w I-ej Instancyi. - Sędzia Prezydujący", tamże, s. 32.

${ }^{89}$ Tamże, s. 33.

${ }^{90}$ K. Małkowski, Przepisy postępowania..., s. 184.

${ }^{91}$ K. Reinhardt, Rzut oka..., s. 110-111.
} 
nych uszczerbków lub chorób ${ }^{92}$. Osoba wezwana na termin sądowy po raz drugi powinna usprawiedliwić swoją nieobecność. W akcie prawnym wydanym przez Komisję Rządową Sprawiedliwości 3/15 grudnia 1853 r. czytamy: „10. Przeciwko stawającemu na drugim dopiero terminie, jeżeli nie usprawiedliwi, że na pierwszym istotnie stanąć nie mógł, będzie wymierzoną przez Sąd kara Kodeksem kar głównych i poprawczych wskazana"93.

W praktyce spotykamy tylko trzy takie opinie. Sąd wzywając na posiedzenie korzystał $\mathrm{z}$ pomocy magistratu. $\mathrm{Z}$ reguły prosił o informację o zachodzącej przeszkodzie $\mathrm{w}$ przybyciu na wskazany termin ${ }^{94}$. Magistrat Miasta Łodzi informował sąd policji prostej lub poprawczej o niemożności stawienia się wezwanej osoby $\mathrm{w}$ sądzie, $\mathrm{z}$ powodu choroby. W jednym $z$ takich przypadków prezydent nie załączył opinii lekarskiej ${ }^{95}$. Sąd Policji Poprawczej Wydziału Łęczyckiego, w piśmie do Prezydenta Miasta Łodzi z 19 września/1 października 1853 r. stwierdził: „Odnośnie do doniesienia z d. 28 sierpnia/9 września r. b. L.4,398 powtórnie wzywa Wgo Prezydenta, ażeby Wincentemu Eberman v. Hebrman natychmiast w Sądzie tutejszym stawić się polecił, skutku dopilnował - jeżeli zaś tenże jest słaby, przeto złożyć winien świadectwo Lekarza - dalsza zwłoka Naczelnikowi Ptu przedstawioną będzie ${ }^{\prime \prime 96}$. W dalszej części akt znajdujemy zaświadczenie lekarza wolnopraktykującego w Łodzi z 10 IX 1853 r, potwierdzające chorobę Ebermanna. Prezydent poświadczył oryginalność podpisu lekarza Schlesingera ${ }^{97}$. Pod koniec opinii z 27 marca/8 kwietnia 1865 r. Lekarz Miasta Łodzi zaświadczył natomiast: „Obie rany są powierzchowne i nie są niebezpieczne - za kilka dni będą zagoione - tenże Studziński może się w Sądzie stawić" ${ }^{\prime \prime 8}$.

${ }^{92}$ Zasady dochodzeń sadowo-lekarskich co do watpliwego stanu zdrowia, wydane przez Rade lekarska redakcyi członka rady A. Janikowskiego, Medycyna sadowa. O watpliwym stanie zdrowia, Warszawa 1845, od s. 200.

${ }^{93}$ O sposobie wzywania osób do stawienia się w Sądach karnych, 8/20 XI 1866 r., Kommissya Rządowa Sprawiedliwości, ZPAKP, OSK, t. XI. Przepisy dotyczace organizacyi sadownictwa karnego, Warszawa 1867, s. 47.

${ }^{94}$ Np. sygn. 1, s. 307.

${ }^{95}$ Przykładowo Magistrat Miasta Łodzi 28 VIII/9 IX 1853 przekazał Sądowi Policji Poprawczej Wydziału Łęczyckiego następującą informację: „,Z powodu, że Wincenty Ebermann v. Habermann jest dotknięty mocną słabością i stawiennictwa na teraz dopełnić nie może". SPPOZ, sygn. 1, s. 322.

${ }_{96}^{6}$ SPPOZ, sygn. 1 [Korespondencja z Prezydentem i Magistratem m. Łodzi], s. 267.

${ }^{97}$ "Zaświadczam niniejszym, że Pan Wincenty Ebermann, tkacz mający lat 51 cierpi na febrę gastryczną - nerwową znajduje się w mojej Kuracyi i jeszcze jest w takim Stanie, że Ebermann nie może odbywać żadnej podróży bez narażenia się na większe niebezpieczeństwo". SPPOZ, sygn. 1 [Korespondencja z Prezydentem i Magistratem m. Łodzi], s. 266.

${ }_{98}$ SPPOZ, sygn. 66, Sprawa przeciwko Stefanowi Schultz o obelgi [i usitowanie zabójstwa], k. 6. Podobnie: SPPOZ, sygn. 65 [Sprawa przeciwko Karolowi Fryderykowi Grylich o pobicie i zagrożenie], 1856, k. 7 . 
Co ciekawe, opinię lekarską znajdujemy też w jednej ze spraw o potwarz. W skardze pewnej wdowy z 15/27 września 1865 r., wśród zarzutów stawianych tkaczowi Grzegorzowi Trasowi czytamy: „,oskarżony nasamprzód usiłował córkę moją Paulinę Ausnern uwieść i zniewolić do cielesnych stosunków jako też i mnie samą i gdyśmy oparły się jego chuciom zdrożnym, powodowany przez to nienawiścią ku nam począł rozgłaszać po mieście, że się trudnimy nierządem a co większa że jesteśmy zarażeni weneryą i że dla tego doniesie o tem policyi aby nas rewidowała a następnie do szpitala na leczenie odesłała"99. Na poparcie swojej skargi poza świadkami, skarżąca przedstawiła opinię lekarza, zaświadczającą o dobrym stanie zdrowia swojej córki. Przy powołaniu się na opinię lekarza skarżąca stwierdziła: „dla wykazania publiczności żeśmy zdrowe a córka moja nienaruszona - zaprowadziłam sama córkę moją Paulinę do Wgo Herzel Lekarza Miasta który po zredwidowaniu jej zaoppniował jak dołączające się świadectwo jego przekonwa"100.

\section{Podsumowanie}

W aktach Sądu Policji Prostej Okręgu Zgierskiego opinie lekarzy znajdujemy najczęściej w sprawach o pobicie i obelgi czynne. Rzadziej w sprawach o potwarz (mamy jeden udokumentowany przypadek). Opinie wydawane były na wniosek pokrzywdzonych, sądu lub organów policyjnych. $Z$ reguły obdukcja dokumentowała stan zdrowia jednej osoby. Znajdujemy jednak kilka przypadków wystawiania zbiorowych opinii. Na przykład 20 sierpnia/1 września lekarz wystawił opinię na wezwanie inspektora policji dla czterech osób i odesłał mu ją ${ }^{101}$.

Forma poświadczenia obrażeń zasadniczo odpowiadała wymogom instrukcji z 1847 r. Lekarze nie wpisywali jednak pod opinią treści przysięgi. Opisy obrażeń i wnioski zawarte w świadectwach spisywane były według obowiązujących wówczas reguł.

Poniższa tabela pokazuje opinie lekarskie, datę ich wydania i ich rolę procesową.

${ }^{99} \mathrm{SPPOZ}$, sygn. 85 [Sprawa przeciwko Georgowi Fras o rozsiewanie oszczerstw], k. 3.

${ }^{100}$ Tamże. W opinii Lekarza Miasta Łodzi czytamy m.in.: „przy zrewidowaniu iey ciała nie znalazłem aby ta ulegała jakie chorobie chroniczney lub zaraźliwey; - i że Paulina Hausern zupełnie dobrego stanu zdrowia", tamże, k. 4.

${ }^{101}$ SPPOZ, sygn. 33 [Sprawa przeciwko Józefowi Berkman i innym o pobicie], 1863, s. 2. Podobnie: SPPOZ, sygn. 41 [Sprawa przeciwko Ferdynandowi Hoffmanowi i innym o napad i pobicie], 1863, s. 5-6; SPPOZ, sygn. 42 [Sprawa przeciwko Augustowi Apszpajgier i innym o napad, pobicie i zniszczenie cudzej własności], 1863, s. 6-7; SPPOZ, sygn. 89, Sprawa przeciwko Gotfriedowi Straus o pobicie, 1865, k. 4. 
Joanna Machut-Kowalczyk

\begin{tabular}{|c|c|c|c|c|c|c|c|c|c|c|c|c|c|c|}
\hline $\begin{array}{l}\text { कू } \\
\text { के }\end{array}$ & - & $a$ & $\underset{工}{\sim}$ & $\rightleftarrows$ & $\stackrel{10}{\sim}$ & iి & $\bar{m}$ & $\ddot{m}$ & $\stackrel{\infty}{\infty}$ & ले & F & ㄱ & $\widetilde{6}$ & ళु \\
\hline 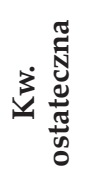 & 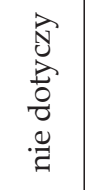 & 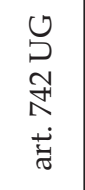 & $\overrightarrow{\dot{\Sigma}}$ & $\overrightarrow{3}$ & $\dot{\overrightarrow{3}}$ & $\overrightarrow{\dot{B}}$ & 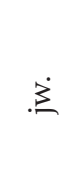 & $\stackrel{\vec{z}}{ }$ & $\vec{\Sigma}$ & 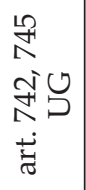 & 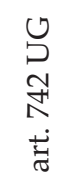 &.$\dot{3}$ & 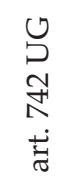 &.$\dot{\overrightarrow{3}}$ \\
\hline 站兌 & 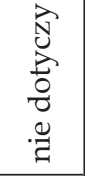 & 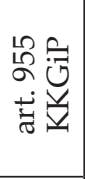 & $\stackrel{\overrightarrow{3}}{.}$ & $\stackrel{3}{3}$ & $\dot{\overrightarrow{3}}$ & 1 & 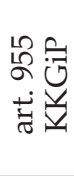 & 1 & 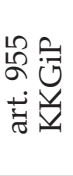 & 1 & 1 & 1 & 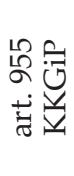 & 1 \\
\hline 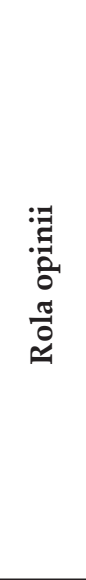 & 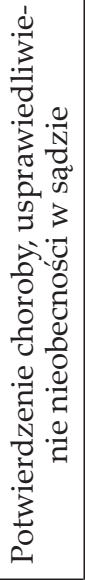 & 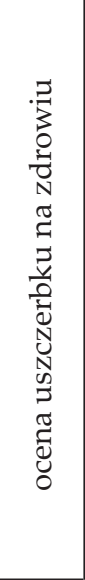 & $\dot{3}$ &.$\dot{3}$ & $\stackrel{\dot{3}}{ }$ & i. &.$\dot{3}$ & $\stackrel{\dot{\vec{z}}}{ }$ & 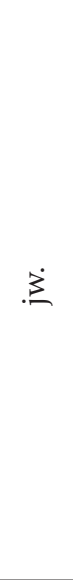 & $\dot{\vec{z}}$ & 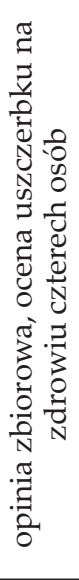 & 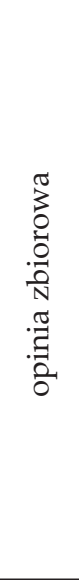 & 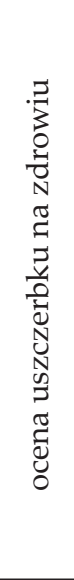 & 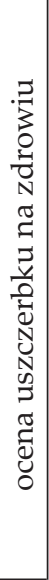 \\
\hline 胥 & 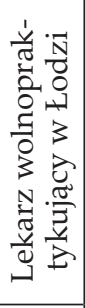 & 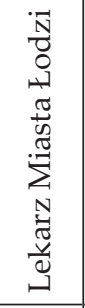 & 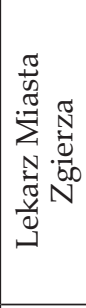 & 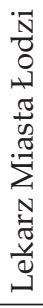 & $\stackrel{\dot{3}}{ }$ & 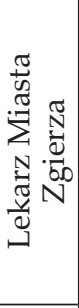 & 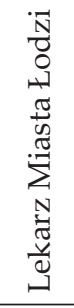 & $\stackrel{\dot{B}}{ }$ & $\dot{\vec{z}}$ & 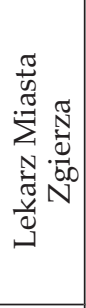 & 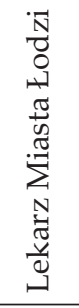 &.$\dot{3}$ &.$\dot{3}$ &.$\dot{3}$ \\
\hline 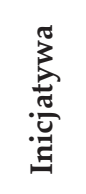 & $\sum_{\bar{\omega}}^{\infty}$ & 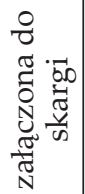 & $\stackrel{\dot{3}}{.}$ & 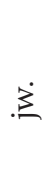 & 1 & 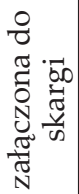 & $\stackrel{\dot{3}}{ }$ & $\stackrel{\overrightarrow{3}}{ }$ &.$\dot{3}$ &.$\dot{3}$ & 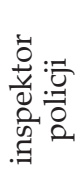 & 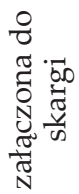 &.$\dot{\underline{3}}$ &.$\dot{3}$ \\
\hline 능 & $\underset{\stackrel{\infty}{\infty}}{\infty}$ & $\begin{array}{l}\qquad 3 \\
\infty \\
-1\end{array}$ & $\begin{array}{l}\text { तै } \\
\infty \\
\sim\end{array}$ & $\begin{array}{l}\text { तै } \\
\infty \\
-\end{array}$ & $\begin{array}{l}\text { तै } \\
\infty \\
\sim\end{array}$ & $\begin{array}{l}\text { ָै } \\
\infty \\
-1\end{array}$ & $\begin{array}{l}8 \\
\infty \\
\infty \\
-1\end{array}$ & $\begin{array}{l}\mathscr{3} \\
\infty \\
-1\end{array}$ & $\begin{array}{l}\text { तै } \\
\infty \\
\sim\end{array}$ & \begin{tabular}{l}
$\mathscr{3}$ \\
$\infty$ \\
\hdashline
\end{tabular} & $\begin{array}{l}\mathscr{8} \\
\infty \\
-1\end{array}$ & $\begin{array}{l}\mathscr{8} \\
\infty \\
-1\end{array}$ & \begin{tabular}{l}
$\not 艹$ \\
$\infty$ \\
\hdashline
\end{tabular} & $\begin{array}{l}+ \\
\infty \\
\infty \\
\sigma\end{array}$ \\
\hline$\dot{\leftrightarrow}$ & -1 & $N$ & $m$ & + & 10 & 6 & $\Lambda$ & $\infty$ & $a$ & $\stackrel{ }{\longrightarrow}$ & 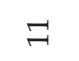 & ㄱ & $\stackrel{m}{\rightarrow}$ & $\exists$ \\
\hline
\end{tabular}


Rola procesowa opinii biegłych lekarzy na przykładzie praktyki Sadu Policji Prostej...

\begin{tabular}{|c|c|c|c|c|c|c|c|c|c|c|c|c|}
\hline 12 & ๑ర & $\infty$ & $\infty$ & $\infty$ & ஓ & హ゙ & হ & $\stackrel{0}{\bullet}$ & $\underset{\rightleftharpoons}{\beth}$ & $\stackrel{\sim}{\rightleftharpoons}$ & $\stackrel{M}{\rightleftharpoons}$ & $\stackrel{\triangle}{\beth}$ \\
\hline 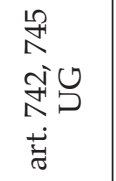 & 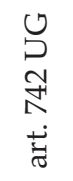 & 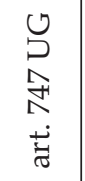 & 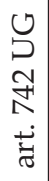 & 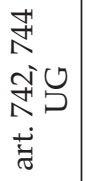 & 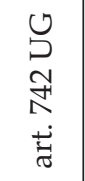 & غ. & 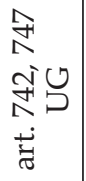 & 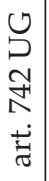 & $\overrightarrow{3}$ & 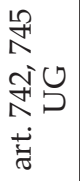 & 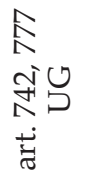 & \begin{tabular}{l}
0 \\
$\vdots$ \\
\multirow{2}{*}{} \\
\multirow{2}{*}{} \\
\multirow{4}{*}{}
\end{tabular} \\
\hline 1 & 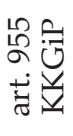 & 1 & 1 & 1 & 1 & 1 & 1 & 1 & 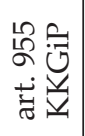 &.$\dot{3}$ & 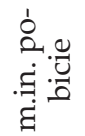 & 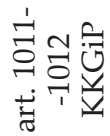 \\
\hline 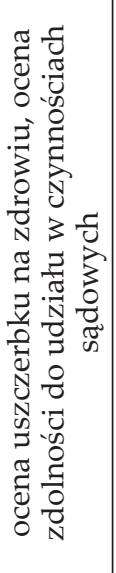 &.$\dot{\vec{z}}$ & 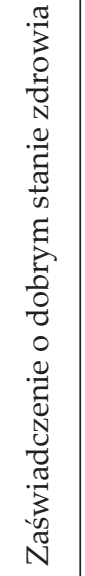 & 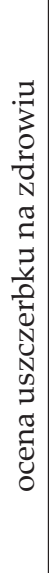 & $\dot{\vec{z}}$ &.$\dot{3}$ &.$\dot{\vec{z}}$ & $\dot{\vec{z}}$ & .3 & $\overrightarrow{3}$ & $\overrightarrow{\dot{B}}$ & $\overrightarrow{\dot{B}}$ &.$\dot{\vec{B}}$ \\
\hline$\dot{\vec{z}}$ & 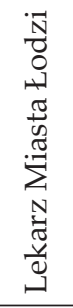 &.$\dot{\underline{\Xi}}$ & $\dot{\vec{B}}$ & $\dot{\vec{z}}$ &.$\dot{3}$ & 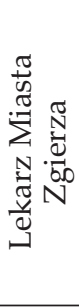 & 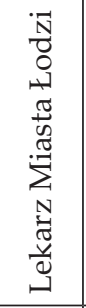 & 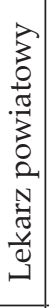 & 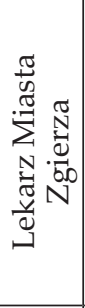 & 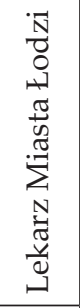 & $\dot{\vec{\Sigma}}$ & 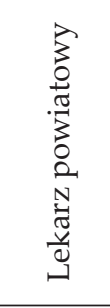 \\
\hline $\begin{array}{l}N \\
0 \\
\vdots \\
\text { के }\end{array}$ & $\begin{array}{l}N \\
0 \\
\hat{n}\end{array}$ & 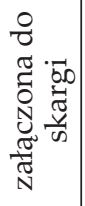 & $\dot{3}$ & 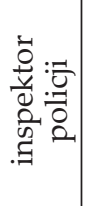 & 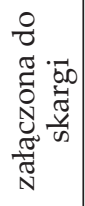 &. & 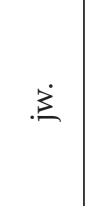 &. & 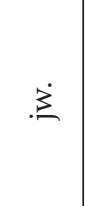 & $\dot{\vec{\Sigma}}$ & 1 & 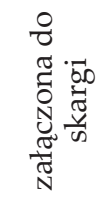 \\
\hline $\begin{array}{l}\qquad 0 \\
\infty \\
-1\end{array}$ & \begin{tabular}{l}
$\stackrel{10}{\infty}$ \\
$\infty$ \\
\hdashline
\end{tabular} & \begin{tabular}{l}
$\qquad 0$ \\
$\stackrel{\infty}{\infty}$ \\
\hdashline
\end{tabular} & $\begin{array}{l}\not 1 \\
\infty \\
-1\end{array}$ & $\begin{array}{l}10 \\
\stackrel{\infty}{\infty} \\
\stackrel{-1}{-1}\end{array}$ & $\begin{array}{l}\qquad 0 \\
\infty \\
-1\end{array}$ & $\begin{array}{l}10 \\
\infty \\
\infty \\
-1\end{array}$ & 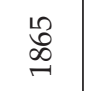 & $\begin{array}{l}\stackrel{a}{b} \\
\infty \\
-1\end{array}$ & $\begin{array}{l}10 \\
\infty \\
\infty\end{array}$ & $\begin{array}{l}10 \\
\infty \\
\rightarrow\end{array}$ & 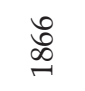 & 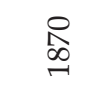 \\
\hline$\stackrel{\Perp}{\longrightarrow}$ & $\stackrel{0}{\sim}$ & 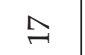 & $\stackrel{\infty}{\sim}$ & $\stackrel{\vartheta}{\rightarrow}$ & ণิ & $\vec{入}$ & ন & $\vec{N}$ & $\vec{\sim}$ & $\stackrel{\llcorner}{N}$ & $\stackrel{\sim}{\sim}$ & તે \\
\hline
\end{tabular}


Udało się pokazać procesowe znaczenie zaświadczeń lekarskich. Zebrane opinie odgrywały najczęściej rolę przy ustalaniu właściwości sądu, rzadziej przy ocenie zdolności osób wezwanych do udziału w postępowaniu sądowym.

W kwalifikowaniu drobnych spraw karnych do art. 742 UG dziwić mogą te, w których pokrzywdzony doznał skaleczeń, siniaków, tym bardziej że takich obrażeń przepis ten nie wymieniał wśród znamion czynu.

Większość zaświadczeń wydana została przez lekarzy miejskich. Nie znajdujemy $w$ aktach konkurencyjnych opinii. Być może ma to związek $\mathrm{z}$ typem spraw zachowanych $\mathrm{w}$ badanym zespole archiwalnym. Sprawy poważniejsze mogły zostać przesłane do Sądu Policji Poprawczej Wydziału Łęczyckiego lub trybunału kryminalnego.

\section{Bibliografia}

\section{Źródła rękopiśmienne}

APŁ, Zespół nr 120: „Sąd Policji Prostej Okręgu Zgierskiego”.

\section{Źródła drukowane}

Dekret z 26 lipca 1810 r. pt. Organizacya Sądów Kryminalnych Wydziatów Policyi poprazoczej $i$ sadów Policyjnych $w$ kraju przez Traktat Wiedeński do Księstwa Warszawskiego dołaczonym, „Dziennik Praw” [Warszawa] 1860, t. LVII.

Instrukcya wskazująca Sadom zasady znoszenia się z zarzadem lekarskim do wszystkich Sadów Kryminalnych, Policyi Poprawczéj i Policyi Prostéj, z 8/20 kwietnia 1839 r., Dyrektor Główny Prezydujący w Komissyi Rządowej Sprawiedliwości, nr 179, Zbiór Przepisów Administracyjnych Królestwa Polskiego, OSK, t. XII. Przepisy dotyczace organizacyi sadownictwa karnego, Warszawa 1867.

Kodex Kar Głównych i Poprawczych, „Dziennik Praw” [Warszawa] 1847, t. XL.

O sposobie wzywania osób do stawienia się w Sąach karnych, 8/20 listopada 1866 r., Kommissya Rzadowa Sprawiedliwości, Zbiór Przepisów Administracyjnych Królestwa Polskiego, cz. II, B. Organizacya sadownictwa karnego, t. XI, Przepisy dotyczace organizacyi sadownictwa karnego, Warszawa 1867.

Ordynacya Kryminalna Pruska, tłum. I. Stawiarski, Warszawa 1828.

Postanowienie wprowadzajace w wykonanie Ustawe o Sadach Gminnych, z 30 maja/11 czerwca 1861 r., Rada Administracyjna, Zbiór Przepisów Administracyjnych Królestwa Polskiego, cz. II, B. Organizacya sadownictwa karnego, t. X, Przepisy dotyczace organizacyi sadownictwa karnego, Warszawa 1867.

Rozporzadzenie, aby na czele protokołów czynności sądowo lekarskich zamieszczany byt urząd osób prowadzacych śledztwo i kwalifikacje lekarzy dopetniajacych obdukcyj, z 29 stycznia 1827 r., Komissya Rzadowa Sprawiedliwości, nr 177, Zbiór Przepisów Administracyjnych Królestwa Polskiego, cz. II, B. Organizacya sadownictwa karnego, t. XII, Przepisy dotyczace organizacyi sadownictwa karnego, Warszawa 1867, s. 389-391. 
Rozporzadzenie, aby Sady o pierwotne opinie co do stanu zdrowia podsadnych, odnosity się nie do Członków Rady Lekarskiéj lub Urzędów Lekarskich, lecz do lekarzy rzadowych lub wolnopraktykujacych, 30 czerwca/11 lipca 1844 r., Kommissya Rzadowa Sprawiedliwości, nr 66, Zbiór Przepisów Administracyjnych Królestwa Polskiego, Wydział Sprawiedliwości, cz. II, B. Organizacya sadownictwa karnego, t. XI, Przepisy dotyczace organizacyi sądownictwa karnego, Warszawa 1867.

Zasady dochodzeń sadowo-lekarskich co do watpliwego stanu zdrowia, wydane przez Radę lekarska redakcyi członka rady A. Janikowskiego, Medycyna sadowa. O watpliwym stanie zdrowia, Warszawa 1845.

Zasady dochodzeń sądowo-lekarskich w przypadkach uszkodzeń ciała, wydane przez Radę lekarska redakcyi członka rady A. Janikowskiego, Medycyna sądowa. O uszkodzeniach ciała, Warszawa 1847.

Zbiór Przepisów Administracyjnych Królestwa Polskiego, Wydziat Sprawiedliwości, cz. II, B. Organizacya sadownictwa karnego, t. IX, Organizacya sadownictwa karnego, Warszawa 1867.

\section{Opracowania}

Budziński S., Wykład porównawczy prawa karnego, Warszawa 1868.

Heylman A., Historya Organizacyi Sądownictwa w Królestwie Polskiem, t. I, Warszawa 1861.

Kutrzeba S., Historya ustroju Polski w zarysie, t. III, cz. I, Po rozbiorach, Lwów 1920. Machut-Kowalczyk J., Początki łódzkiego sądownictwa, „Studia z Dziejów Państwa i Prawa Polskiego" [Kraków] 2014.

Małkowski K., Przepisy postępowania sadowego w sprawach karnych. Wykład zasad procedury karnej. Dodatki historyczne. Prawo obowiazujace. Ordynacya Kryminalna Pruska i późniejsze prawodawstwo, Warszawa 1865.

N., Zasady dochodzeń sadowo-lekarskich w przypadkach uszkodzeń ciała, wydane przez radę Lekarska Królestwa Polskiego. Redakcyi Członka Rady Profesora A. Jankowskiego, "Tygodnik Lekarski” [Warszawa] 1847, s. 201.

Reinhardt K., Rzut oka na urządzenie Stużby Zdrowia w królestwie Polskiém, „Biblioteka Warszawska. Pismo poświęcone naukom, sztukom, i przemysłowi" [Warszawa] 1846, t. III.

Smyk G., Przestępstwa przeciwko czci i nietykalności osobistej w prawie karnym II Rzeczypospolitej, [w:] Przestępstwa przeciwko czci i nietykalności cielesnej, red. M. Mozgawa, Warszawa 2013.

Taylor S., Ustrój sądowy w Księstwie Warszawskim i Królestwie do roku 1876-go, „Gazeta Sądowa Warszawska” [Warszawa] 1918, nr 41. 